\title{
MADŽARSKA V LUČI OBISKA TURISTOV IZ SLOVENIJE - PROSTORSKA RAZPOREDITEV TURISTIČNEGA PROMETA IN SPLETNE PONUDBE
}

\author{
dr. Miha Koderman*, dr. Simon Kerma**, \\ Tomaž Kostanjšek, dipl. org. tur. ${ }^{* * *}$ \\ *Oddelek za geografijo, Fakulteta za humanistične študije, \\ Univerza na Primorskem \\ Titov trg 5, Sl-6000 Koper/Capodistria \\ **Fakulteta za turistične študije - Turistica, Univerza na Primorskem \\ Obala I la, SI-6320 Portorož/Portorose \\ ****Novellus d.o.o. \\ Brezovce 8, SI- 1236 Trzin \\ e-pošta: miha.koderman@fhs.upr.si, simon.kerma@fts.upr.si, t.kostanjsek@novellus.si
}

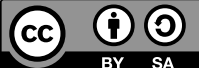

Izvirni znanstveni članek

COBISS 1.01

DOI: 10.4312/dela.47.1.85-105

\section{Izvleček}

$\mathrm{V}$ prispevku so predstavljene poglavitne značilnosti potovanj turistov iz Slovenije na Madžarsko. Uvodoma je podan pregled ključnih turističnih kazalcev te države, ki se v nadaljevanju podrobneje osredotoči na turiste iz Slovenije in njihovo vlogo v strukturi tujih obiskovalcev. Drugi del prispevka povzema glavne izsledke analize spletne ponudbe organiziranih turističnih potovanj, ki jo oglašujejo slovenske turistične agencije. Ponudba je bila predmet prostorske in vsebinske (pogostost pojavljanja oglaševanih destinacij, vrsta storitev, trajanje in cena) analize.

Ključne besede: Madžarska, turisti iz Slovenije, organizirana turistična potovanja, analiza spletne turistične ponudbe, turistične agencije

\section{SLOVENIAN TOURISTS IN HUNGARY - SPATIAL DISTRIBUTION OF TOURIST FLOWS AND ANALYSIS OF THE INTERNET-BASED TOURISM SERVICES}

\begin{abstract}
The article examines the main characteristics of tourist visits of Slovenians to Hungary. Authors first present an overview of the statistic indicators, where a special emphasis is given to the Slovenian tourists and their role among other international visitors. The second part of the article summarizes the main findings of the analysis of the internet-based
\end{abstract}


tourist services (organized tourist trips), provided by Slovenian travel agencies. The services were subject of spatial and contextual (frequency of the advertised destinations, type of service, duration and price) analysis.

Key words: Hungary, tourists from Slovenia, organized travel packages, analysis of the internet-based tourist offer, travel agencies

\section{UVOD}

Madžarska se je že pred desetletji uveljavila kot pomembna turistična destinacija, ki privablja turistične tokove iz vsega sveta. Država je v letu 2015 beležila več kot 10 milijonov prihodov turistov, pri čemer se naglo povečuje število tujih turistov, ki v zadnjih letih doživlja rekordno rast. V letu 2008 je bilo tako na Madžarskem evidentiranih 3,5 milijona prihodov tujih obiskovalcev, v letu 2015 pa je njihovo število doseglo 4,9 milijona (HCSO [Hungarian Central Statistical Office], 2016a). Država se ponaša z raznoliko turistično ponudbo, ki zajema številna termalna zdravilišča, obsežna zavarovana območja narave $\mathrm{z}$ visoko stopnjo biotske pestrosti in bogato kulturno ter arhitekturno dediščino nekdanje avstro-ogrske monarhije, ki je še posebej izrazita v prestolnici Budimpešti. Izjemnost posameznih krajev je prepoznala tudi Organizacija združenih narodov za izobraževanje, znanost in kulturo, ki je 8 območij v državi uvrstila na seznam svetovne naravne (1 enota) in kulturne dediščine (7 enot) (UNESCO [United Nations Educational, Scientific and Cultural Organization], 2017). Turisti se poleg tega navdušujejo tudi nad madžarskimi kulinaričnimi in vinskimi izdelki ter specialitetami in mednarodno prepoznavnimi festivalskimi prireditvami.

Madžarska je zaradi geografske bližine, zgodovinskih, družbenih in političnih okoliščin tradicionalno priljubljena destinacija tudi za obiskovalce in turiste iz Slovenije, ki jo zaradi različnih motivov obiskujejo preko celega leta. Obravnavano državo je po oceni Statističnega urada Republike Slovenije v letu 2014 obiskalo okoli 46.000 turistov iz Slovenije, ki so tja potovali individualno ali organizirano in pri tem ustvarili najmanj eno prenočitev, kar to državo po številu izvedenih potovanj v tuje države uvršča na osmo mesto (SURS [Statistični urad RS], 2016a). Madžarski statistični urad za leto 2014 sicer beleži prihode 26.314 slovenskih turistov, ki so ustvarili 51.503 nočitve (HCSO, 2016b). V pričujoči raziskavi želimo opredeliti glavne značilnosti (organiziranih) turističnih potovanj slovenskih turistov na Madžarsko, pri čemer se osredotočamo zlasti na njihov številčni obseg, vrsto in tip storitev, po katerih Slovenci kot turistični potrošniki povprašujejo, ter prostorsko usmeritev njihovega obiska po madžarskih regijah.

\section{METODOLOŠKI PRISTOP}

Prispevek je vsebinsko in metodološko razdeljen v tri večje sklope. V prvem delu temelji na razpravi teoretične narave, kjer smo s pomočjo analize vsebine relevantne 
strokovne in znanstvene literature postavili teoretični okvir. V drugem delu smo analizirali statistične podatke o turističnem obisku turistov iz Slovenije na Madžarskem, pri čemer so bili uporabljeni podatki tako slovenskega kot madžarskega statističnega urada. Tretji del prispevka vsebuje pregled spletne ponudbe slovenskih turističnih agencij, ki organizirajo potovanja na Madžarsko. Ta del raziskave je metodološko osnovan na predhodno opravljenih analizah turistične ponudbe slovenskih turističnih agencij za hrvaško primorje (Kerma, Koderman, Salmič, 2009), Bosno in Hercegovino (Koderman, Kerma, 2010) ter Avstrijo (Kežar, Koderman, 2014). Pri tem smo izhajali iz podatkovne baze Gospodarske zbornice Slovenije, ki upravlja z evidenco organizatorjev potovanj (GZS, 2015). V prvi fazi je raziskava zajemala identifikacijo vseh turističnih agencij oziroma organizatorjev potovanj, ki ponujajo turistične storitve na območju obravnavane države. Ponudba izbranih podjetij je bila nato predmet vsebinske analize in je zajemala različne vidike oglaševanih storitev (pogostost pojavljanja oglaševanih destinacij, vrsta storitev, trajanje in cena).

\section{MADŽARSKA KOT TURISTIČNA DESTINACIJA}

Madžarska se je začela tujim obiskovalcem odpirati v začetku 60-ih let 20. stoletja, ko je prišlo do omilitve komunističnega režima, in odtlej beleži stalni porast turističnega obiska (HCSO, 2016c). Turizem se je na tem območju sicer razvijal že v obdobju avstro-ogrske monarhije, ko so obiskovalci posamezne destinacije obiskovali predvsem iz zdravstvenih razlogov, saj je bil glavni poudarek na termalnih zdraviliščih (Kocsis, Schweitzer, 2009). Madžarska danes goste vabi s sloganom »Think Hungary, more than expected «, pri čemer glavno turistično destinacijo predstavlja glavno mesto Budimpešta (Tourism in Hungary, 2015). V kolikor turistični sektor razčlenimo glede na motiv obiska, lahko ugotovimo, da so na Madžarskem prisotne predvsem naslednje vrste turizma: 1) obiskovanje kulturnih in naravnih znamenitosti, pri čemer so v ospredju predvsem prestolnica Budimpešta in kraji, ki so pod zaščito Unescove kulturne dediščine; 2) obiskovanje zdravilišč in term, saj ima tovrstni turizem zaradi ugodne geološke sestave tal možnosti razvoja na celotnem območju Madžarske; 3) obiskovanje kongresnih prireditev (Kocsis, Schweitzer, 2009; Pečoler, 2013).

Madžarska sodi med petindvajset najbolj obiskanih držav sveta, saj je v letu 2014 na omenjeni lestvici zasedla 23. mesto (UNWTO [World Tourism Organization], 2015). Ob pregledu ekonomskih kazalnikov turističnega sektorja lahko ugotovimo, da je preučevana panoga k celotnemu bruto družbenemu proizvodu Madžarske (v nadaljevanju BDP) v letu 2015 skupno prispevala 10,4 \%, poleg tega pa je bilo znotraj turistične panoge neposredno ali posredno zaposlenih skorajda pol milijona ljudi (oziroma 428.500 oseb) (WTTC [World Travel \& Tourism Council], 2016a). Omenjene ekonomske kazalnike prikazujemo tudi v preglednici 1 , kjer primerjamo izbrane turistične pokazatelje za leto 2015 na Madžarskem in v Sloveniji. 
Preglednica 1: Primerjava izbranih ekonomskih kazalcev na Madžarskem in v Sloveniji za leto 2015.

\begin{tabular}{|l|l|l|}
\hline $\mathbf{2 0 1 5}$ & Madžarska & Slovenija \\
\hline Delež turističnega BDP v celotnem BDP & $10,4 \%$ & $13,0 \%$ \\
\hline Število zaposlenih & $428.500(10,0 \%)$ & $107.000(13,3 \%)$ \\
\hline Število prihodov (domači in tuji turisti) & $10.403,000$ & $3.927,530$ \\
\hline Število nočitev & $25.888,000$ & $10.341,699$ \\
\hline Povprečna dolžina bivanja (dan) & 2,5 & 2,6 \\
\hline Delež prihodov domači/tuji gostje & $52,6 \%$ (domači) $47,4 \%$ (tuji) & $31,0 \%$ (domači) $69,0 \%$ (tuji) \\
\hline
\end{tabular}

Vir: WTTC, 2016a; WTTC, 2016b; HCSO, 2016a; SURS, $2016 b$.

V letu 2015 je Madžarsko obiskalo 10.402 .900 turistov, pri čemer za nekaj odstotkov prednjačijo domači obiskovalci, saj je bilo le-teh 52,6 \% (HCSO, 2016a). V obdobju med letoma 2001 in 2015 je sicer prihajalo do nihanj v številu prihodov, negativen trend na vseh ravneh (v skupnem številu, pri domačih in tujih obiskovalcih) pa je opazen zlasti v letu 2009, čeprav je tudi v drugih obdobjih prihajalo do posameznih negativnih odklonov.

Madžarski turizem je v letu 2015 beležil skoraj 26 milijonov opravljenih nočitev (25.888.000), pri čemer je bilo le nekoliko več nočitev ustvarjenih s strani tujih gostov $(50,1 \%)$ kot domačih $(49,9 \%)$ (HCSO, 2016a). Na sliki 1 prikazujemo število opravljenih nočitev po posameznih mesecih v letu 2015.

Slika 1: Število nočitev po posameznih mesecih leta 2015.

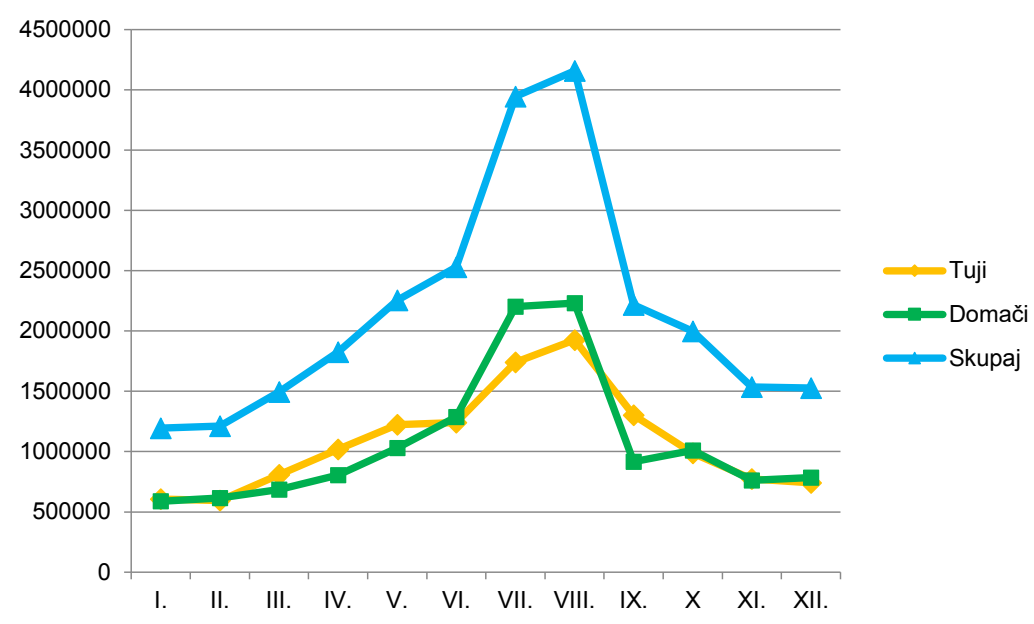

Vir: HCSO, $2016 b$. 
Iz slike 1 je opazna sezonskost turističnega obiska, saj obiskovalci največ nočitev opravijo v poletnih mesecih, z viškom v juliju in avgustu. Število nočitev je sicer v porastu v prvi polovici leta, v poletnem obdobju le-te doživijo vrh, nato pa sledi nagel upad. Glede na dejstvo, da je na Madžarskem močno prisoten zdraviliški turizem, bi lahko pričakovali, da bodo opravljene nočitve enakomerneje razporejene skozi celo leto, vendar je, kot že omenjeno, opazno močno številčno povečanje nočitev zgolj v poletnem obdobju (HCSO, 2016b). Omenjena sezonskost je značilna za vse turistične regije Madžarske, pri čemer pa je bila več kot polovica $(57,8 \%)$ opravljenih nočitev v letu 2015 zgoščena v zgolj dveh turističnih regijah - Osrednji Madžarski in regiji Blatno jezero. Prostorsko razporeditev opravljenih nočitev glede na poreklo turistov prikazujemo v nadaljevanju na sliki 2. Najmanj nočitev je bilo v letu 2015 zabeleženih v turistični regiji Jezero Tisa (1,1\%), nizek odstotek nočitev pa beleži tudi regija Južno Prekodonavje (4,1 \%) (HCSO, 2016b). Na tem mestu naj dodamo, da je Madžarska od leta 1996 administrativno razdeljena na sedem statističnih regionalnih enot (NUTS 2 regije) in jo tako sestavljajo naslednje regije: Zahodno Prekodonavje (Nyugat-Dunántúl), Osrednje Prekodonavje (Közép-Dunántúl), Južno Prekodonavje (Dél-Dunántúl), Osrednja Madžarska (Közép-Magyarország), Severna Madžarska (Észak-Magyarország), Severna velika nižina (Észak-Alföld) in Južna velika nižina (Dél-Alföld) (Kocsis, Schweitzer, 2009). Ministrstvo za gospodarstvo je v letu 2000 za potrebe turizma na Madžarskem omenjenim sedmim regijam priključilo še posebni enoti Blatno jezero (Balaton) in regijo Jezero Tisa (Tisza-tó) (Tourism in Hungary, 1990-2002). Odločitev za povzemanje turističnih in ne statističnih regionalnih enot v tem prispevku je bila sprejeta tudi zaradi dejstva, da madžarski statistični urad za potrebe prikaza statističnih pokazateljev s področja turizma prav tako uporablja členitev po turističnih regijah. Omenjeni urad podatke sicer prikazuje tako za statistične kot turistične regije, pri čemer pa podatke, ki so za pričujoči prispevek najbolj bistveni (podatki o prostorski razporeditvi po posameznih regijah glede na poreklo turistov), prikazujejo na osnovi turističnih regij. Zgoraj navedena imena regij smo poslovenili na podlagi izvirnega in angleškega poimenovanja.

Slika 2 nam da dober vpogled v prostorsko razporeditev opravljenih nočitev po posameznih turističnih regijah Madžarske glede na poreklo turistov. Iz slike je tako razvidno, da so v letu 2015 v regiji Osrednja Madžarska glede na število opravljenih nočitev močno prevladovali tuji turisti $(81,35 \%)$, medtem ko je v preostalih regijah višji delež domačih gostov (HCSO, 2016b).

Povprečna doba bivanja je na Madžarskem v zadnjem desetletju precej upadla, in sicer se je z 2,8 dni znižala na 2,5 dni, pri čemer je upad tega kazalnika pri tujih turistih še precej izrazitejši. Slednji so v letu 2005 na Madžarskem bivali 3,1 dneva, v letu 2015 pa le še 2,6 dneva (HCSO, 2016a). Statistični urad Madžarske spremlja tudi kazalnike o povprečni dobi bivanja po posameznih turističnih regijah, med katerimi ima najdaljšo dobo bivanja regija Blatno jezero, in sicer 4,7 dneva (HCOS, 2016a). V tem primeru lahko predpostavljamo, da ima omenjena turistična regija najdaljšo povprečno dobo bivanja zaradi turistične privlačnosti Blatnega jezera, kjer posamezniki preživljajo počitnice, medtem ko se na drugih destinacijah zadržujejo krajši čas. Turistični regiji z najkrajšo 
Slika 2: Delež opravljenih nočitev tujih in domačih gostov po posameznih turističnih regijah Madžarske v letu 2015.

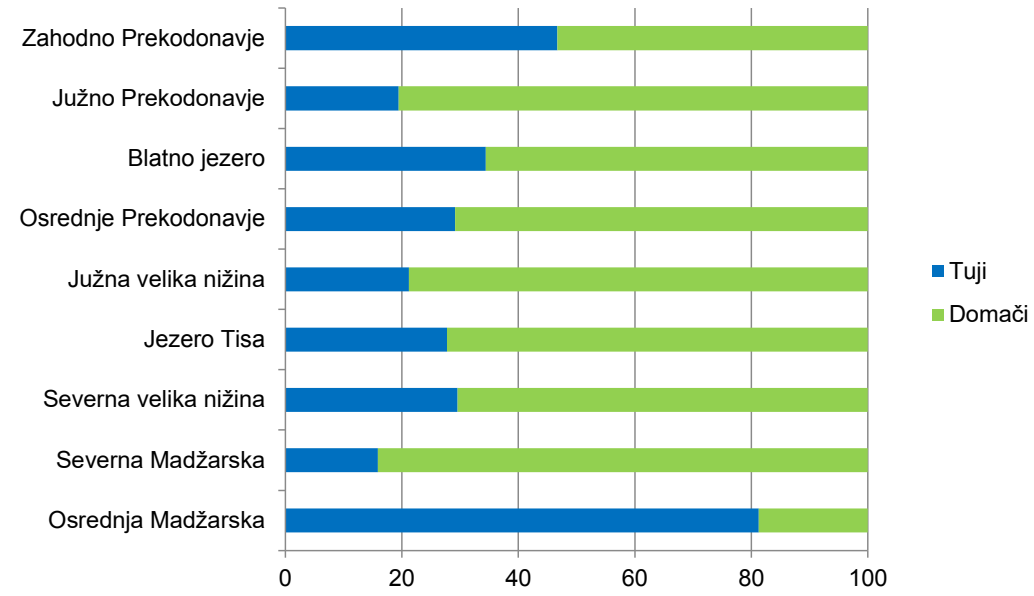

Vir: HCSO, $2016 b$.

povprečno dobo bivanja (2,3 dneva) sta Južna velika nižina in najbolj obiskana madžarska regija Osrednja Madžarska (HCSO, 2016a).

Preglednica 2: Število nočitev glede na poreklo turistov s posameznih celin med letoma 2012 in 2015.

\begin{tabular}{|l|l|l|l|l|l|l|l|l|}
\hline & $\mathbf{2 0 1 2}$ & $\mathbf{\%}$ & $\mathbf{2 0 1 3}$ & $\mathbf{\%}$ & $\mathbf{2 0 1 4}$ & $\mathbf{\%}$ & $\mathbf{2 0 1 5}$ & $\mathbf{\%}$ \\
\hline Evropa & 9.878 .386 & 86,7 & 10.203 .763 & 85,3 & 10.389 .291 & 84,1 & 10.667 .445 & 82,3 \\
\hline Azija & 738.603 & 6,5 & 863.578 & 7,2 & 948.771 & 7,7 & 1.135 .780 & 8,8 \\
\hline $\begin{array}{l}\text { Severna } \\
\text { Amerika }\end{array}$ & 529.038 & 4,6 & 606.863 & 5,1 & 681.425 & 5,5 & 778.024 & 6,0 \\
\hline Južna Amerika & 106.879 & 0,9 & 134.738 & 1,1 & 136.873 & 1,1 & 144.098 & 1,1 \\
\hline $\begin{array}{l}\text { Avstralija in } \\
\text { Oceanija }\end{array}$ & 76.126 & 0,7 & 101.613 & 0,8 & 111.194 & 0,9 & 132.038 & 1,0 \\
\hline Afrika & 40.085 & 0,4 & 50.684 & 0,4 & 59.394 & 0,5 & 74.742 & 0,6 \\
\hline $\begin{array}{l}\text { Srednja } \\
\text { Amerika }\end{array}$ & 23.066 & 0,2 & 21.644 & 0,2 & 24.382 & 0,2 & 30.268 & 0,2 \\
\hline SKUPAJ & 11.392 .183 & 100,0 & 11.982 .883 & 100,2 & 12.351 .330 & 100,0 & 12.968 .395 & 100,0 \\
\hline
\end{tabular}

Vir: HCSO, $2016 b$.

Iz porekla turistov (preglednica 2) glede na izvorno celino ugotovimo, da je v obdobju med letoma 2012 in 2015 največ obiskovalcev, ki so na Madžarskem prenočevali, prihajalo iz Evrope, je pa ob tem treba poudariti, da se absolutni delež gostov iz Evrope 
vsako leto manjša, povečuje pa se delež gostov iz Azije (HCSO, 2016b). Podoben trend lahko opazimo tudi v sosednjih državah, ki beležijo znaten porast števila obiskovalcev iz azijskih držav (Koderman, Gosar, 2017).

V kolikor se osredotočimo na nočitve, opravljene glede na izvorno državo obiskovalcev, lahko ugotovimo, da so v letu 2015 največ nočitev opravili gosti iz Nemčije (1.963.119 oziroma 15,1 \%), katerim so sledili obiskovalci iz Velike Britanije (891.358 oziroma 6,9 \%) in Avstrije (791.675 oziroma 6,1 \%). Več kot petodstotni delež so k nočitvam prispevali še obiskovalci iz Češke, Italije in Združenih držav Amerike, lestvico prvih desetih držav pa zaključujejo Poljska, Rusija in Romunija. Vse naštete države, z izjemo Združenih držav Amerike, so evropske, kar se sklada z že omenjenim dejstvom, da večino nočitev na Madžarskem opravijo obiskovalci iz Evrope, pri čemer slovenski turisti, glede na opravljene nočitve, zavzemajo 33. mesto med vsemi državami. Z azijske celine največ nočitev realizirajo gosti iz Kitajske (222.540), med gosti iz Južne Amerike pa jih največ prihaja iz Brazilije (72.323). Zanimanje slednjih za Madžarsko bi lahko povezali s tem, da najštevilčnejša madžarska izseljenska skupnost v Južni Ameriki prihaja ravno iz omenjene države (Papp, 2011). Glede na dejstvo, da statistični podatki izkazujejo, da je glavni motiv tujih turistov za obisk Madžarske obiskovanje prijateljev in sorodnikov (ang. VFR tourism) (Tourism in Hungary, 2015), bi lahko v navedenem primeru govorili tudi o t. i. turizmu iskanja korenin (Koderman, 2015).

\section{ZNAČILNOSTI POTOVANJ TURISTOV IZ SLOVENIJE NA MADŽARSKO}

Madžarska je bila med slovenskimi turisti, poleg znamenitosti, ki jih ponuja Budimpešta, v začetku 90-ih let 20. stoletja poznana zlasti po nakupovalnem turizmu, ko so bila predvsem obmejna madžarska mesta in vasi polna kupcev iz Slovenije. V tistem času so do najbolj poznanega tovrstnega nakupovalnega centra v obmejnem mestu Lenti vozili tudi posebni nakupovalni avtobusi, ki so svoj vrh doživeli leta 1995, ko je bilo na mejnem prehodu Dolga vas zabeleženih več kot 20.000 enodnevnih nakupovalnih avtobusov, njihovo število pa je kasneje hitro upadlo. Razloge za to gre iskati v dejstvu, da so se v sredini 90-ih let tudi v Sloveniji začele pojavljati trgovine in večja nakupovalna središča, kjer je bilo mogoče kupiti cenejše oziroma ceneno blago (Litrop, 2003).

Slovenski turisti Madžarske dandanes ne povezujejo več (zgolj) s poceni nakupovanjem, temveč jih privabljata mestni turizem (ogled kulturnih in zgodovinskih znamenitosti, kulinarika, kulturno dogajanje) in zdravstveni oziroma velnes turizem. Omenjena dejstva lahko zapišemo na podlagi opravljene analize ponudbe, ki jo slovenske turistične agencije tržijo v primeru obiska Madžarske. S podobo Madžarske kot turistične destinacije v Sloveniji z vidika turističnih podjetij in turistov se je v svojem magistrskem delu ukvarjala Pečolerjeva (2013). Avtorica ugotavlja, da slovenski turisti Madžarske kot turistične destinacije ne prepoznavajo v dovolj veliki meri, saj večina obiskovalcev obravnavano državo povezuje zgolj z Budimpešto in delno Blatnim jezerom, preostala ponudba pa jim ni dobro poznana (Pečoler, 2013). 


\section{I Število prihodov in nočitev turistov iz Slovenije na Madžarsko}

Podatki madžarskega statističnega urada prikazujejo omenjene podatke le za obdobje po letu 2011, zaradi česar težko ugotavljamo dejansko krivuljo turističnega prometa, saj petletno obdobje predstavlja nezadosten časovni okvir za natančnejše zaključke. Iz preglednice 3 je razvidno, da število prihodov turistov iz Slovenije, z izjemo leta 2014, upada. Upadu prihodov sledi tudi upad števila nočitev, pri čemer je izjema leto 2012, ko je bilo kljub temu, da je bilo prihodov manj kot leto poprej, opravljenih $10,8 \%$ več nočitev (HCSO, 2016b).

Turisti iz Slovenije so v letu 2015 sicer predstavljali skromnih $0,25 \%$ vseh prihodov turistov na Madžarsko, v kolikor pa delež slovenskih turistov primerjamo zgolj s tujimi obiskovalci, znaša 0,53 \%, kar Slovenijo po številu prihodov turistov na Madžarsko uvršča na 35. mesto (HCSO, 2016b).

Preglednica 3: Število prihodov in nočitev turistov iz Slovenije na Madžarskem ter indeks spreminjanja števila prihodov in nočitev turistov med letoma 2011 in 2015.

\begin{tabular}{|l|l|l|l|l|l|}
\hline & $\begin{array}{l}\text { Število } \\
\text { prihodov }\end{array}$ & $\begin{array}{l}\text { Indeks } \\
(\%)\end{array}$ & $\begin{array}{l}\text { Število } \\
\text { nočitev }\end{array}$ & $\begin{array}{l}\text { Indeks } \\
(\%)\end{array}$ & $\begin{array}{l}\text { Povprečna doba } \\
\text { bivanja }\end{array}$ \\
\hline 2011 & 27.571 & $100 \%$ & 55.451 & $100 \%$ & 2,0 \\
\hline 2012 & 27.171 & 98,5 & 61.453 & 110,8 & 2,3 \\
\hline 2013 & 26.906 & 97,6 & 53.587 & 96,6 & 2,0 \\
\hline 2014 & 28.530 & 103,5 & 54.383 & 98,1 & 1,9 \\
\hline 2015 & 26.314 & 95,4 & 51.503 & 92,9 & 2,0 \\
\hline
\end{tabular}

Vir: HCSO, $2016 b$.

Podatki statističnega urada kažejo, da slovenski turisti potujejo na Madžarsko le za krajše časovno obdobje, ki je v letu 2015 znašalo 2 dni. Slednje se ujema z dejstvom, da je večina (spletne) ponudbe, ki je na voljo slovenskim turistom s strani turističnih agencij, zajemala krajša potovanja, ki največkrat obsegajo do dve nočitvi.

\section{2 Število prihodov in nočitev turistov iz Slovenije po turističnih regijah Madžarske}

V obravnavnem obdobju, ki je zajemalo petletno obdobje med letoma 2011 in 2015, smo ugotovili, da slovenski turisti najbolj množično obiskujejo turistično regijo Osrednja Madžarska, kar je v skladu z dejstvom, da je omenjeno območje najbolj obiskana madžarska turistična regija nasploh. Ta turistična regija vsako leto beleži okoli 15.000 prihodov slovenskih turistov (14.945 v letu 2015). Regiji Osrednja Madžarska sledi regija Blatno jezero s približno 5.000 prihodi slovenskih turistov (4.974 v letu 2015), preostale regije pa beležijo manjši obisk. Število prihodov slovenskih turistov po posameznih turističnih regijah Madžarske prikazujemo tudi v preglednici 4 in sliki 3. V obravnavanem obdobju 
v posameznih turističnih regijah prihaja do nihanj pri številu prihodov, predvsem pa je za najbolj obiskane regije v zadnjem letu značilen manjši številčni upad, medtem ko ostale regije v letu 2015 beležijo nekoliko večje število prihodov. Takšen primer so regije Južno Prekodonavje ter Južna in Severna velika nižina (HCSO, 2016b).

Preglednica 4: Število prihodov slovenskih turistov po posameznih turističnih regijah Madžarske med letoma 2011 in 2015.

\begin{tabular}{|l|l|l|l|l|l|l|l|l|l|l|}
\hline & \multicolumn{2}{|c|}{2011} & \multicolumn{2}{c|}{2012} & \multicolumn{2}{c|}{2013} & \multicolumn{2}{c|}{2014} & \multicolumn{2}{c|}{2015} \\
\cline { 2 - 11 } & Prihodi & $\%$ & Prihodi & $\%$ & Prihodi & $\%$ & Prihodi & $\%$ & Prihodi & $\%$ \\
\hline $\begin{array}{l}\text { Osrednja } \\
\text { Madžarska }\end{array}$ & 16.587 & 60,2 & 15.093 & 55,5 & 15.912 & 59,1 & 16.450 & 59,1 & 14.945 & 56,8 \\
\hline Blatno jezero & 5.476 & 19,9 & 5.183 & 19,1 & 4.956 & 18,4 & 5.795 & 18,4 & 4.974 & 18,9 \\
\hline $\begin{array}{l}\text { Zahodno } \\
\text { Prekodonavje }\end{array}$ & 1.813 & 6,6 & 2.273 & 8,4 & 1.902 & 7,1 & 2.532 & 7,1 & 2.158 & 8,2 \\
\hline $\begin{array}{l}\text { Južno } \\
\text { Prekodonavje }\end{array}$ & 997 & 3,6 & 1.427 & 5,3 & 1.149 & 4,3 & 954 & 4,3 & 1.046 & 4,0 \\
\hline $\begin{array}{l}\text { Severna velika } \\
\text { nižina }\end{array}$ & 795 & 3,3 & 1.186 & 2,9 & 1.071 & 2,5 & 665 & 2,5 & 908 & 3,0 \\
\hline $\begin{array}{l}\text { Osrednje } \\
\text { Prekodonavje }\end{array}$ & 451 & 2,9 & 654 & 4,4 & 746 & 4,0 & 882 & 4,0 & 873 & 3,5 \\
\hline $\begin{array}{l}\text { Južna velika } \\
\text { nižina }\end{array}$ & 904 & 1,9 & 787 & 1,7 & 682 & 1,6 & 543 & 1,6 & 784 & 2,2 \\
\hline $\begin{array}{l}\text { Severna } \\
\text { Madžarska }\end{array}$ & 521 & 1,6 & 459 & 2,4 & 434 & 2,8 & 663 & 2,8 & 578 & 3,3 \\
\hline Jezero Tisa & 27 & 0,1 & 109 & 0,4 & 54 & 0,2 & 46 & 0,2 & 48 & 0,2 \\
\hline SKUPAJ & 27.571 & 100,0 & 27.171 & 100,0 & 26.906 & 100,0 & 28.530 & 100,0 & 26.314 & 100,0 \\
\hline
\end{tabular}

Vir: HCSO, $2016 b$.

Obiskanost turističnih regij v letu 2015 prikazujemo tudi na sliki 3, iz katere je jasno razvidna vloga turistične regije Osrednja Madžarska s prestolnico Budimpešto kot vodilnega turističnega območja v državi.

Število opravljenih nočitev s strani slovenskih turistov v posameznih turističnih regijah Madžarske je, preračunano na deleže, le v primeru dveh turističnih regij (Osrednje Madžarske in Osrednjega Prekodonavja) manjše od števila prihodov. Tako kot prihaja do nihanj med posameznimi leti pri številu prihodov, je stanje podobno glede na opravljene nočitve. Edina turistična regija, ki v obravnavanem petletnem obdobju beleži nenehno številčno rast opravljenih nočitev, je regija Osrednje Prekodonavje (HCSO, 2016b).

V zaključku pregleda izbranih statističnih kazalcev turistov iz Slovenije predstavljamo še povprečno dobo bivanja v posameznih turističnih regijah Madžarske med letoma 
Slika 3: Zemljevid madžarskih turističnih regij ter deleži prihodov turistov iz Slovenije v letu 2015.

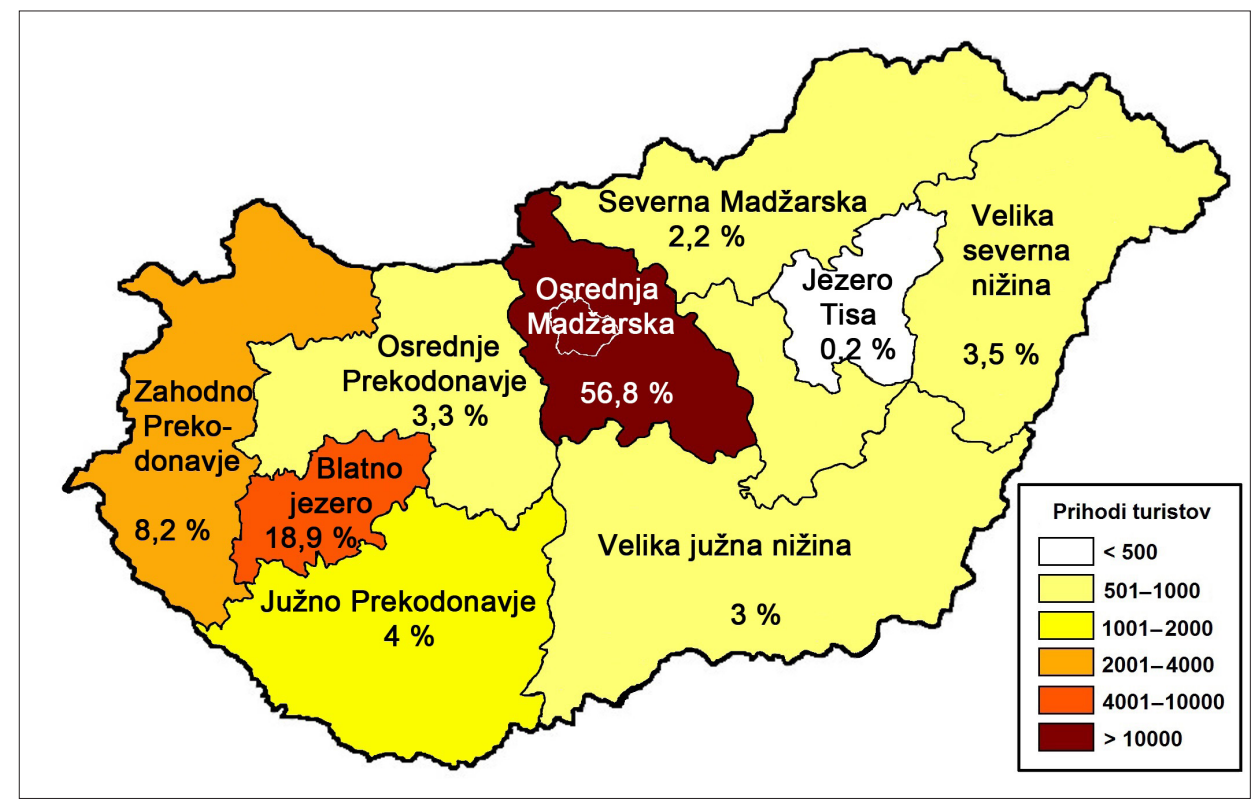

Vir: Lastna raziskava; prirejeno po HCSO, 2016b; Itthon.hu, 2016.

2011 in 2015. Slovenski turisti so v letu 2015 povprečno najdlje bivali v regiji Severna Madžarska (2,5 dni), medtem ko je povprečna doba bivanja v regijah Severna velika nižina, Južna velika nižina, Blatno jezero in Zahodno Prekodonavje znašala 2,3 dni. Zgolj iz statističnih podatkov je sicer težko soditi, zakaj je stanje po posameznih turističnih regijah takšno, vendar pa bi lahko sklepali, da je število nočitev povezano tudi z oddaljenostjo posamezne regije. Turistični regiji Blatno jezero in Zahodno Prekodonavje sta lokacijsko sicer najbližje slovenski meji, vendar pa lahko domnevamo, da v njunem primeru na povprečno dobo bivanja vpliva tudi namen potovanja. Regiji sta poznani po zdraviliškem turizmu, zaradi česar je mogoče sklepati, da posamezni turisti iz Slovenije na tem območju preživljajo tudi počitnice, slednje pa navadno zajemajo daljše časovno obdobje (HCSO, 2016b).

\section{ANALIZA SPLETNE TURISTIČNE PONUDBE ZA MADŽARSKO}

V sklopu pričujoče raziskave smo analizirali spletno ponudbo vseh turističnih agencij v Sloveniji, ki imajo licenco organizatorja potovanj. Podatke o turističnih agencijah smo pridobili na spletni strani Gospodarske zbornice Slovenije (v nadaljevanju GZS), ki tovrstne licence tudi podeljuje. Analiza spletne ponudbe je bila opravljena 
v obdobju med 15. novembrom 2015 in 5. januarjem 2016. Zasnova raziskave metodološko temelji na predhodno opravljenih analizah turistične ponudbe slovenskih turističnih agencij v hrvaškem primorju (Kerma, Koderman, Salmič, 2009), Bosni in Hercegovini (Koderman, Kerma, 2010) ter Avstriji (Kežar, Koderman, 2014) in Avstraliji (Koderman, 2015).

V času opravljanja analize je bilo na spletni strani GZS evidentiranih 455 turističnih agencij z licenco organizatorja potovanj. V prvi fazi zbiranja podatkov smo izločili 84 turističnih agencij (18,5\%), ki niso zadostile kriteriju, da mora imeti agencija svojo spletno stran. Izmed preostalih 370 ponudnikov s spletno stranjo pa je bilo le 86 takih $(23,2 \%)$, ki so na svojih spletnih straneh ponujali turistične storitve, nanašajoče se na Madžarsko. Slednje so bile nato predmet podrobnejše analize.

\section{I Prostorski razpored turistične ponudbe po posameznih regijah Madžarske}

Opravljena analiza spletne turistične ponudbe slovenskih organizatorjev potovanj nam je dala dober vpogled v to, katere destinacije se na Madžarskem izkazujejo kot najprivlačnejše za slovenske turiste. Osredotočili smo se na prostorski razpored turistične ponudbe po posameznih regijah, analiza pa je pokazala, da turistične agencije v svoji spletni ponudbi najpogosteje oglašujejo madžarsko prestolnico ter posamezne kraje ob Blatnem jezeru (največkrat vas Tihany). Iz spletnih turističnih programov agencij je razvidno, da se precejšen segment ponudbe nanaša tudi na ogled zgodovinsko pomembnih mest (primer aranžmaja - Gradovi Madžarske), pri čemer je skorajda povsod vključen tudi obisk Budimpešte. Le manjši del ponudbe izpušča obisk prestolnice in se osredotoča na turistična območja v južnem in zahodnem delu države. Najpogosteje oglaševane madžarske turistične destinacije predstavljamo v preglednici 5.

Preglednica 5: Najpogosteje oglaševane destinacije v spletni ponudbi slovenskih turističnih agencij.

\begin{tabular}{|l|l|l|}
\hline Regija & Vrsta storitve & Trajanje (dni) \\
\hline Osrednja Madžarska & Izlet, potovanje - krajše & $1-2$ \\
\hline Blatno jezero/Zahodno Prekodonavje & Izlet, potovanje - krajše & $1-2$ \\
\hline Blatno jezero, Osrednja Madžarska, Osrednje Prekodonavje & Potovanje - krajše & $2-3$ \\
\hline Južno Prekodonavje & Izlet, potovanje - krajše & $1-2$ \\
\hline Zahodno Prekodonavje & Izlet & 1 \\
\hline
\end{tabular}

Vir: Lastna raziskava.

Deleži oglaševane spletne turistične ponudbe po posameznih madžarskih regijah se odražajo v že predstavljenih najpogosteje oglaševanih destinacijah iz preglednice 5, saj se je kar $73 \%$ vse ponudbe navezovalo na regijo Osrednja Madžarska, kamor spada 
tudi Budimpešta, in regijo Blatno jezero. Prostorski razpored spletne turistične ponudbe prikazujemo v sliki 4, iz katere je dobro razvidna osrednja destinacijska usmerjenost turističnih agencij.

Slika 4: Deleži spletne ponudbe slovenskih turističnih agencij po turističnih regijah Madžarske.

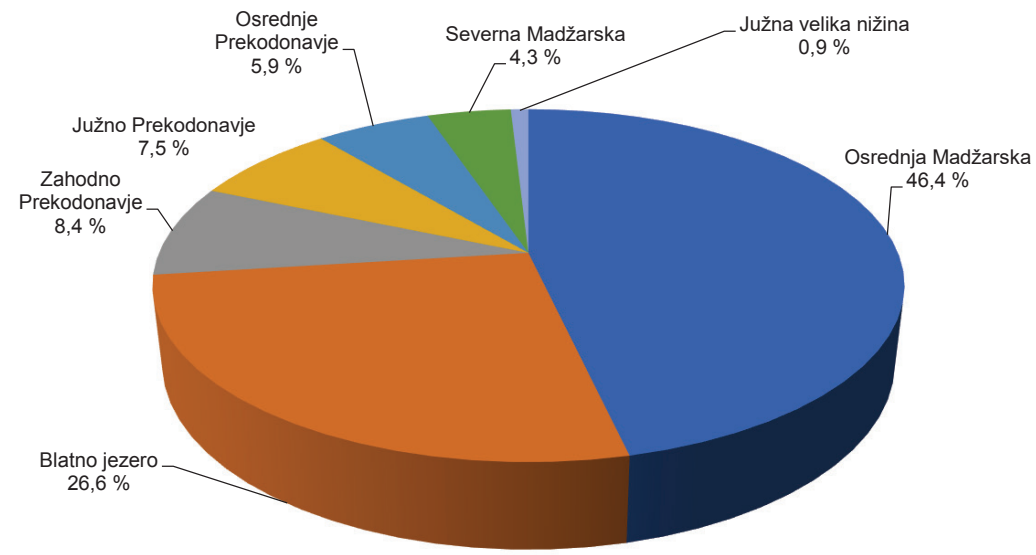

\section{Vir: Lastna raziskava.}

V kolikor omenjene izsledke primerjamo s podatki madžarskega statističnega urada, ki obravnavajo delež prihodov slovenskih turistov po posameznih regijah Madžarske, lahko ugotovimo dokajšnje ujemanje. Slednje je razvidno tudi iz slike 5, ki kaže, da je precejšnje ujemanje med spletno ponudbo in deležem prihodov mogoče zaslediti v večini madžarskih turističnih regij. Madžarski statistični urad sicer beleži 3,5 \% prihodov slovenskih turistov v regiji Severna velika nižina, medtem ko omenjene regije ni bilo mogoče najti v spletni ponudbi turističnih agencij. Odstopanja med spletno ponudbo organizatorjev turističnih potovanj in podatki o prihodih statističnega urada Madžarske lahko delno pojasnimo s tem, da sta obravnavani kategoriji medsebojno težko primerljivi, saj ne gre za obravnavo sorodnih podatkov, poleg tega pa smo se soočili z različnim časovnim zajemom podatkov - podatki o prihodih se nanašajo na celotno leto 2015, medtem ko smo spletno ponudbo analizirali le v zimskem (natančneje prednovoletnem) obdobju leta 2015.

Kot je bilo že omenjeno, je v regiji Osrednja Madžarska, na katero se sicer nanaša 46,4 \% vse oglaševane spletne ponudbe, najbolj zastopana destinacija glavno mesto Budimpešta, ki se v spletni ponudbi pojavlja tako sama kot v kombinaciji z drugimi destinacijami. Pogosto je obisk Budimpešte združen z ogledom kulturno-zgodovinskih mest v bližnji okolici prestolnice (Szentendre, Višegrad, Gödöllő itd.), precej pa je bilo tudi aranžmajev, ki so oglaševali ogled prestolnic različnih držav v kratkem časovnem obdobju (npr. Budimpešta, Praga, Bratislava in Dunaj). Najpogosteje oglaševana ponudba je združevala ogled znamenitosti dveh regij - Budimpešte v Osrednji Madžarski in vasi 
Slika 5: Primerjava spletne ponudbe in prihodov slovenskih turistov po posameznih regijah Madžarske.

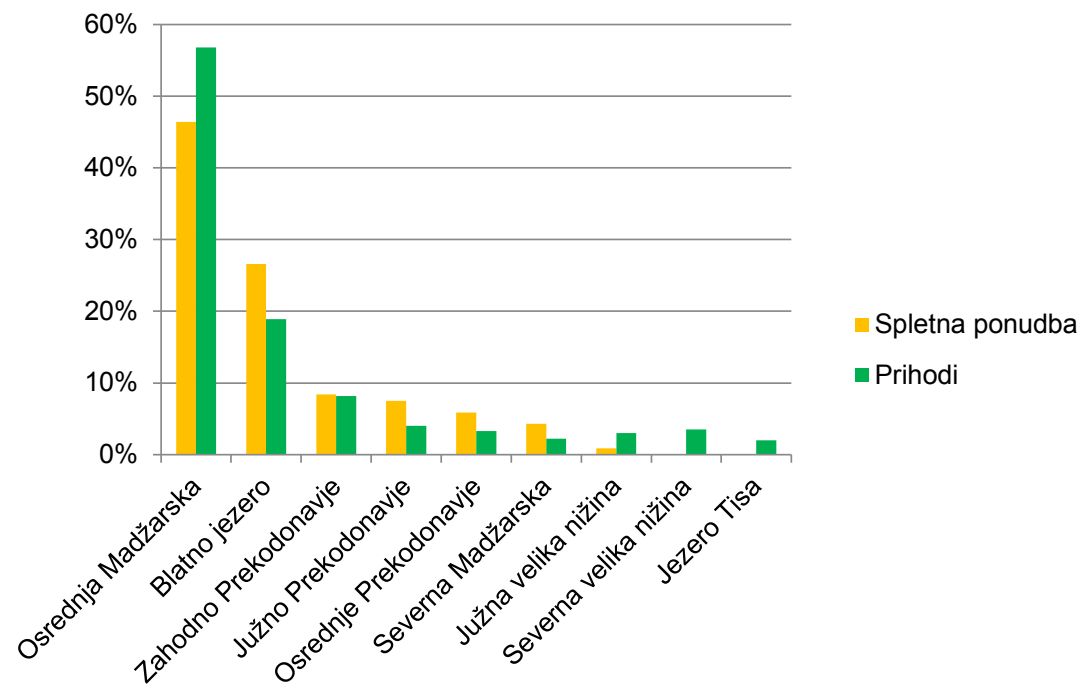

Vir: Lastna raziskava; HCSO, $2016 b$.

Tihany v regiji Blatno jezero. V kolikor se osredotočimo na znamenitosti, ki so bile pri posamezni destinaciji v Osrednji Madžarski izpostavljene v spletni ponudbi, lahko ugotovimo, da so v primeru Budimpešte turistični programi agencij skorajda identični. Itinerariji tako največkrat ponujajo ogled naslednjih glavnih znamenitosti: parlamenta, opere, Štefanove cerkve, sprehod po Trgu junakov, mestnem parku, Vajda Hunyadijevem dvorcu in ulici Váci, ogled mestne tržnice in Grajskega hriba ter razgled na mesto s Citadele. V turističnih programih je, v primeru prenočitve v Budimpešti, obiskovalcem navadno dana možnost večerje v čardi, ki pa običajno ni vključena v samo ceno potovanja. Preostala mesta Osrednje Madžarske, ki jih najdemo v spletni ponudbi turističnih agencij, vabijo s svojimi baročnimi zgradbami in vidnimi ostanki nekdaj močno prisotne srbske skupnosti (mesto Szentendre) ali pa v primeru Višegrada, nekdanje prestolnice srednjeveške Madžarske, z mestnim obzidjem in s Salamonovim stolpom.

Največja turistična privlačnost regije Blatno jezero je vsekakor istoimensko jezero; območje je s 26,6 \% oglaševanih aranžmajev na drugem mestu med madžarskimi regijami. Največ oglaševane ponudbe na spletu v tej regiji zavzema vas Tihany, kot ključni zanimivosti te objezerske vasi pa turistične agencije izpostavljajo etnološki muzej na prostem in benediktinski samostan. Poleg vasi Tihany sta v regiji v turističnih programih večkrat omenjena tudi kraja Keszthely, kjer si obiskovalci ogledajo palačo Festetics in muzej marcipana, ter Siófok, ki slovi po pestrem uličnem dogajanju z raznovrstnimi prireditvami. 
Blatno jezero je sicer del regije Zahodno Prekodonavje, vendar sta ti območji za potrebe turistične statistike madžarskega statističnega urada obravnavani ločeno, zaradi česar jih tudi prikazujemo posebej. Delež spletne ponudbe, ki se nanaša na regijo Zahodno Prekodonavje, je v primerjavi z Osrednjo Madžarsko in Blatnim jezerom znatno manjši $(8,4 \%)$, kljub temu pa turistične agencije strankam ponujajo pester izbor destinacij $\mathrm{v}$ tej regiji. Številni aranžmaji so se navezovali na kraje, ki ležijo v bližini slovensko-madžarske meje in so slovenskim obiskovalcem zanimivi zaradi tam živeče slovenske manjšine, ter kraje v bližini Blatnega jezera.

Na območju skrajnega zahoda Madžarske, ki leži neposredno ob slovenski meji, lahko ugotovimo, da je ponudba osredotočena predvsem na dva kraja slovenskega Porabja, in sicer na Monošter, ki velja za središče slovenskega Porabja, poleg tega pa se ponaša z največjo baročno cerkvijo na Madžarskem, ter Gornji Senik, kjer si obiskovalci ogledajo cerkev sv. Janeza Krstnika in spominsko hišo pisatelja Janoša Küharja. Iz pregleda spletne ponudbe je razvidno, da je v tem delu Madžarske možno obiskati tudi narodni park Örség in manjše kraje, ki so povezani s slovenskim etničnim ozemljem (Sola, Verica-Ritkarovci). V nadaljevanju navajamo kraje, na katere se je v regiji Zahodno Prekodonavje nanašalo manjše število spletnih aranžmajev, ter v oklepajih podajamo kratka pojasnila o njihovih znamenitostih: Šopron (ogled starega mestnega jedra s požarnim stolpom in ogled rimske naselbine), Kiseg (grajska utrdba, baročne hiše), Fertőd (baročni grad Esterhazy) in Gjur (baročno staro jedro). V bližini Blatnega jezera se nahaja poznano termalno zdravilišče Hévíz, ki velja za eno največjih termalnih jezer na svetu. Ob pregledu ponudbe za regijo Zahodno Prekodonavje vidimo, da je le-ta veliko bolj raznolika kot v primeru Osrednje Madžarske, medtem ko jo z regijo Blatno jezero težje primerjamo, saj gre v slednjem primeru za precej manjše območje, ki posledično pomeni tudi manjše število krajev, katere lahko obiščemo.

V kolikor strnemo še spletno ponudbo turističnih agencij, ki se je navezovala na preostale regije, lahko ugotovimo, da je le-ta precej enolična, saj potencialnim obiskovalcem ponuja le malo izbire. V primeru regije Južno Prekodonavje (7,5 \% vse ponudbe) se največje število aranžmajev nanaša na mesto Pécs, poznano tudi kot mesto porcelana, obisk osrednjega mesta regije pa je možno združiti z ogledom mesta Villány (ogled vinske kleti ter pokušina vin). Le nekaj aranžmajev v tej regiji je oglaševalo obisk mesta Sombotel (najstarejše madžarsko mesto, ki leži ob nekdanji jantarski trgovski poti in kjer so zelo dobro ohranjeni rimski ostanki). Turistična spletna ponudba nam podaja tudi možnost obiska regije Osrednje Prekodonavje (5,9 \%), saj se je nekaj aranžmajev nanašalo tudi na kraje v bližini Blatnega jezera, in sicer na Sümeg (grad in ogled srednjeveških iger), Tapolco (razvejan sistem kraških jam s podzemno reko) in Veszprém (katedrala, mestna hiša, požarni stolp, vrata junakov, vzpon na grajski grič). V analizi smo pri tem, sicer tudi športno poznanem mestu, pogrešali ponudbo ogleda rokometnih tekem.

Turistične agencije v svojih aranžmajih oglašujejo Madžarsko tudi kot deželo vin (predvsem tokaja) in organizirajo izlete v regijo Severna Madžarska (4,3 \%), kjer obiskovalci obiščejo mesti Eger in Tokaj. Skromen del spletne ponudbe se je nanašal na regijo Južna velika nižina $(0,9 \%)$, kamor posamezne turistične agencije obiskovalce vabijo na ogled narodnega parka zgodovinske dediščine Ópusztaszer in na trgatev paprike v vasi 
ter mesta, kot so Kalocsa (ogled muzeja paprike), Kecskemét (ogled mesta z baročnim trgom), Hajós (ogled vinske kleti), Kecel (ogled vojaškega muzeja). Na tem mestu naj dodamo, da je Južna velika nižina poznana tudi po obširni travnati pokrajini, imenovani pusta, in številne turistične agencije so imele v svojih programih naveden obisk ene od tradicionalnih madžarskih kmetij. Glede na to, da v večini primerov ni bilo zapisane točne lokacije posestva, smo se odločili, da puste pri izračunu deleža prostorskega razporeda spletne turistične ponudbe po posameznih regijah ne upoštevamo, saj nismo mogli z gotovostjo trditi, da se posamezno posestvo res nahaja $v$ regiji Južna velika nižina.

$\mathrm{V}$ času opravljanja raziskave spletne ponudbe turističnih agencij nismo zasledili programa, v katerem bi bila ponujena možnost obiska regije Tisa ali regije Severna velika nižina.

\subsection{Vrsta in trajanje turističnih storitev}

V nadaljevanju predstavljamo delež posamezne storitve, pri čemer smo slednje razvrstili v sedem kategorij, in sicer izlet, potovanje - krajše (od ena do tri nočitve), potovanje - daljše (več kot tri nočitve), križarjenje, velnes, nastanitev in drugo. Vrste storitev sicer prikazujemo tudi na sliki 6 .

Največji delež med vrstami storitev je zavzela kategorija »krajša potovanja« (56 \%), v sklopu katere je več kot 90 \% spletnih aranžmajev vključevalo tudi ogled Budimpešte. Znotraj te vrste storitev smo evidentirali tri aranžmaje za sindikalne izlete, medtem ko storitev za katero drugo specifično skupino turistov (šolarje, upokojence) v spletni ponudbi turističnih agencij nismo zasledili. Če se osredotočimo na trajanje te vrste storitev, lahko ugotovimo, da je na 58,7 \% krajših potovanj opravljena le ena nočitev, v primerih takšnih aranžmajev pa sta najpogosteje oglaševana programa ogled Budimpešte in postanek ob

Slika 6: Evidentirane kategorije turističnih storitev in njihovi deleži.

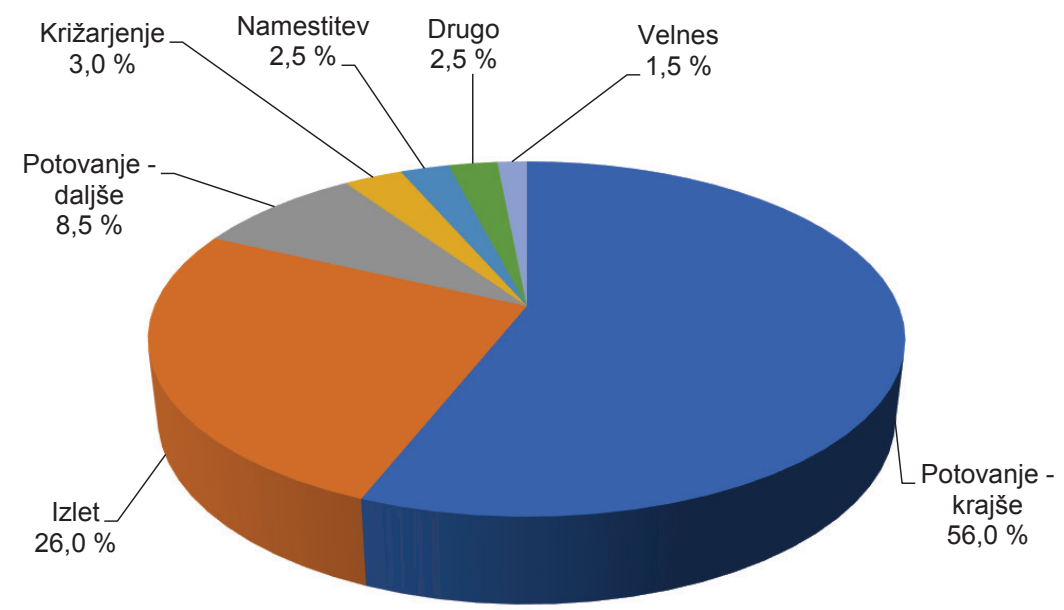

Vir: Lastna raziskava. 
Blatnem jezeru. V programih, ki ponujajo dve nočitvi $(35,1 \%)$, gostje v večini primerov obe nočitvi opravijo v Budimpešti, pri čemer si poleg glavnega mesta ogledajo tudi njegovo bližnjo okolico (Szentendre, Višegrad, Gödöllö itd.) in eno od turističnih vasi ob Blatnem jezeru. Aranžmajev, ki bi vključevali tri nočitve, je manj kot $10 \%$ in lokacijsko poleg obiska Blatnega jezera ter Budimpešte z bližnjo okolico največkrat vključujejo še postanek v enem izmed vinorodnih krajev v regiji Severna Madžarska.

Druga najbolj množična vrsta storitev je »izlet« (26\%), kamor je bila uvrščena vsa spletna ponudba, ki je oglaševala oglede posameznih mest in znamenitosti ter ni vsebovala nočitve. Izletniška ponudba se je lokacijsko v dobri polovici primerov nanašala na ogled Budimpešte, preostali del je v večini primerov zajemal obisk krajev in znamenitosti v regiji Zahodno Prekodonavje ter v okolici Blatnega jezera, le trije aranžmaji pa so se nanašali na obisk mesta Pécs v regiji Južno Prekodonavje.

V kategoriji »Potovanje - daljše«, ki zavzema 8,5 \% delež med vrstami storitev, je ponudba poleg obiska Madžarske vključevala še postanke v različnih državah predvsem srednje in vzhodne Evrope. Štirje aranžmaji so bili namenjeni specifičnim skupinam, in sicer maturantom, motoristom in kolesarjem. V kategoriji daljših potovanj je bil časovni razpon trajanja storitev precejšen, saj smo zabeležili aranžmaje, katerih programi so trajali vse od pet do devetnajst dni. Pri programih, ki so bili časovno obsežnejši (več kot dvanajst dni), smo predvidevali, da so v prvi vrsti namenjeni tujcem, saj so bili ti programi potovanj objavljeni v angleškem jeziku.

Tri odstotke vseh aranžmajev so zavzemala križarjenja po Donavi, v sklopu katerih posameznik poleg Budimpešte največkrat obišče še Bratislavo in Dunaj, v primeru dveh aranžmajev tudi Prago. Ponudba križarjenj je bila časovno zelo raznolika in je obsegala razpon trajanja od tri do enajst dni. Glede na delež vrste storitev je križarjenju sledila ponudba nastanitev $\mathrm{v}$ apartmajih in mobilnih hišicah $(2,5 \%)$, ki se je lokacijsko nanašala le na dve območji, in sicer na Budimpešto in Blatno jezero.

V kategoriji »drugo« (2,5\%) smo zajeli tiste vrste storitev, ki so se v spletni ponudbi pojavile največ dvakrat. V tej skupini smo tako združili dva aranžmaja za obisk koncerta, en aranžma za prevoz z vlakom na relaciji Ljubljana-Budimpešta, en aranžma z možnostjo lova na divjad in en aranžma za strokovno ekskurzijo v tovarno avtomobilov. Slednjo bi sicer lahko uvrstili tudi v kategorijo »izlet« ali »potovanje«, ker pa v programu ekskurzije ni bilo zabeleženo, koliko časa le-ta traja, smo se odločili, da jo zaradi časovne nedoločljivosti ne uvrstimo k omenjenima skupinama. Pri ponudbi lova na divjad je bilo navedeno, da je za goste organizirano prenočevanje, nikjer pa nismo našli podatka, ali gre za eno ali več nočitev.

Najmanjši delež analizirane spletne ponudbe (1,5 \%) je pripadel kategoriji »počitnice/ velnes«, pri čemer so bili vsi aranžmaji vezani na območje Blatnega jezera in so zajemali od štiri do pet dni v enem izmed termalnih zdravilišč.

\subsection{Osnovne cene turističnih aranžmajev}

V kolikor se poleg vrste in trajanja turističnih storitev osredotočimo še na ceno posameznega aranžmaja, lahko opazimo, da med istovrstnimi turističnimi storitvami prihaja 
do precejšnjih cenovnih razponov. V kategoriji »izlet« je bila povprečna cena izleta 48 EUR, pri čemer se cena aranžmaja med posameznimi agencijami giblje od 25 do 82 EUR. Natančne vzroke za tako velik cenovni razpon je sicer samo iz pregleda spletne ponudbe težko ugotoviti, kljub temu pa lahko po natančno opravljeni analizi podamo nekaj mnenj. V primeru najcenejšega izleta (25 EUR) je bil ponudnik storitve iz bližine slovensko-madžarske meje in tudi sam izlet je lokacijsko zaobjel območje slovenskega Porabja, kar pomeni, da organizator izleta ni imel večjih stroškov s prevozom. Pri izletih, ki so bili cenovno najdražji (82 EUR), je vzroke visoke cene težje pojasnjevati, saj organizatorja izleta s programom nista odstopala od preostale ponudbe, tudi sedež podjetij se nahaja v vzhodni Sloveniji, zaradi česar ne pričakujemo visoke cene samega prevoza. V ceno storitve sta bila sicer pri vseh organizatorjih izleta vključena prevoz ter obisk ene ali več destinacij s strokovnim vodenjem.

Pri najobsežnejši ponudbi turističnih storitev, to je krajšem potovanju, se je cenovni razpon gibal med 45 in 413 EUR, v povprečju pa je potovanje stalo 136 EUR. Cena potovanj, ki so trajala dva dni (teh je bilo 58,3 \%), je bila med 45 in 139 EUR, pri čemer so na ceno med drugim vplivale kakovost nastanitve in dodatne storitve, ki so bile vključene $\mathrm{v}$ ceno poleg prevoza in strokovnega vodenja. Pri posameznih turističnih aranžmajih je bila v ponudbo vključena tudi večerja s tipično madžarsko kulinariko (t. i. večer v čardi), manjši del ponudbe pa je vključeval tudi vožnjo z ladjo po Donavi. Omenjeni storitvi sta bili sicer na voljo pri skorajda vseh ponudnikih, vendar z doplačilom. Cena spletne ponudbe, ki je imela v programu tridnevni obisk (takšnih je bilo $34,9 \%$ ), se je gibala med 85 in 390 EUR, do velikega cenovnega odstopanja pa prihaja zaradi razlike v obsežnosti programa in dodatnih storitev (poleg že omenjene večerje $\mathrm{v}$ čardi in vožnje $\mathrm{z}$ ladjo po Donavi še obisk vinskih kleti in pokušina vin), ki so bile pri dražjih aranžmajih v večini primerov že vključene v ceno. Krajših potovanj, ki so trajala štiri dni, je bilo znotraj te skupine le 6,8 \%, njihova cena pa je bila od 239 do 413 EUR. Najdražji programi so vključevali silvestrovanje v enem izmed termalnih zdravilišč ob Blatnem jezeru, ponudba pa je zajemala tudi izlete ob obali jezera.

Potovanja, ki so obsegala pet ali več dni, so v povprečju stala 1.226 EUR; cenovni razpon se je sicer gibal med 279 in 5.420 EUR. Na povprečno višino cene aranžmaja vplivajo štiri potovanja, ki so bila časovno daljša od 14 dni, njihova cena pa je bila od 1.435 EUR dalje. Cena omenjenih programov je visoka ne samo zaradi časovne dolžine posameznih potovanj, temveč tudi zaradi tega, ker vključuje obisk več evropskih držav in njihovih znamenitosti. Zaradi specifičnosti teh itinerarijev (trajanje, cena in ponudba, pisana v angleškem jeziku) lahko sklepamo, da so bili v prvi vrsti namenjeni tujim obiskovalcem, ki želijo spoznati Evropo.

Raznolika cenovna ponudba se je pojavila tudi v primeru križarjenj, kjer prav tako ugotavljamo, da na ceno vplivajo trajanje oziroma različen časovni obseg posameznih križarjenj, tip kabine na ladji oziroma kategorija hotela in dodatne storitve. Povprečna cena križarjenja je znašala 784,50 EUR, pri čemer je bila cena najcenejše ponudbe 109 EUR in je trajala le dva dni. Najdražje križarjenje je stalo 2.547 EUR, trajalo je 11 dni ter vključevalo kar osem različnih postankov v štirih državah (Madžarska, Češka, Slovaška in Avstrija). Pri ponudbi križarjenj moramo omeniti pomembno razliko med 
posameznimi programi, saj nekateri organizatorji potovanj prenočitve nudijo v hotelih, spet drugi pa imajo nočitev organizirano na ladji.

Ponudba, ki je vključevala najem nastanitev, se je gibala med 39 in 59,50 EUR, povprečna cena najema apartmaja ali mobilne hišice pa je bila 43 EUR.

Pri kategoriji »drugo« je cena povprečnega aranžmaja znašala 106,60 EUR. Cenovno najdražji v tej kategoriji je bil lov na divjad (285 EUR), kar je verjetno posledica tega, da so v ceno vključena tudi vsa potrebna dovoljenja za odstrel. Najcenejša ponudba se je nanašala na prevoz z vlakom na relaciji Ljubljana-Budimpešta (19 EUR), cena za obisk koncerta je znašala nekaj več kot 100 EUR, ogled tovarne avtomobilov pa je bil možen za 39 oziroma 75 EUR.

Pri ponudbi počitnic/velnesa je bila povprečna cena aranžmaja 774 EUR. Ob tem je treba izpostaviti, da je bila ponudba vezana na različno časovno trajanje (štiri ali pet dni); cenovno se je razlikovala tudi zaradi različnih kategorij nastanitve in prehrane, saj so nekateri aranžmaji vključevali le zajtrk (večina pa je sicer nudila polpenzion).

\section{ZAKLJUČEK}

Iz analizirane literature in statističnih virov lahko razberemo, da je Madžarska kljub svoji relativno majhni površini ena izmed turistično privlačnejših držav tako na evropski kot na globalni ravni. V obdobju od leta 2001 do leta 2015 je država povečala število turističnih prihodov domačih in tujih obiskovalcev za več kot $71 \%$. Turisti iz Slovenije so leta 2015 v tej državi ustvarili 26.314 prihodov in 51.503 nočitev in tako v strukturi madžarskega turizma ne predstavljajo pomembnejšega deleža (njihov delež med vsemi tujimi turisti v omenjenem letu znaša le $0,53 \%$, kar Slovenijo po številu prihodov turistov uvršča na 35. mesto). Ob tem je treba dodati, da navedeni podatki predstavljajo zgolj tiste turiste, ki v tej državi opravijo vsaj eno nočitev, zato lahko sklepamo, da bi bilo število obiskovalcev iz Slovenije še precej višje, v kolikor bi lahko spremljali tudi enodnevne individualne izlete na Madžarsko.

Po opravljeni analizi 86 slovenskih turističnih agencij, ki so ponujale turistične storitve za Madžarsko, smo ugotovili, da so med najpogosteje oglaševanimi paketi prevladovala krajša potovanja (z večinskim, 56-\% deležem znotraj vseh analiziranih vrst storitev), sledili pa so jim organizirani izleti (s 26-\% deležem). Omenjena krajša potovanja in izleti so bili v splošnem geografsko usmerjeni zlasti v mesto Budimpešta ter območje Blatnega jezera. Na omenjeni turistični regiji je bilo v času raziskovanja osredotočenih skupno kar $82 \%$ vseh analiziranih turističnih storitev, v letu 2015 pa sta privabili skupno $75,7 \%$ vseh registriranih turistov iz Slovenije.

V osrednjem delu pričujoče razprave smo z analizo različnih sklopov podatkov prišli do več ugotovitev, ki so se nanašale na ujemanje prostorske osredotočenosti turistične ponudbe, oglaševane s strani slovenskih potovalnih agencij, ter evidentiranih kazalnikov madžarskega statističnega urada o realiziranih prihodih in nočitvah slovenskih turistov. Ujemanje lahko označimo kot visoko, o čemer nazorno govori tudi slika 5 (Primerjava spletne ponudbe in prihodov slovenskih turistov po posameznih regijah Madžarske). 
Na koncu lahko še kritično dodamo, da bi bilo za poglobljeno poznavanje značilnosti organiziranih turističnih potovanj turistov iz Slovenije na Madžarsko dobrodošlo opraviti tudi strukturirane intervjuje z glavnimi agencijskimi ponudniki, ki organizirajo izlete in potovanja $v$ to državo. Poleg tega bi bilo raziskovanje spletne turistične ponudbe slovenskih agencij smiselno izvesti v več presečnih obdobjih v letu, saj bi takšna študija nedvomno podala celovitejšo sliko tako o prostorski osredotočenosti turistične ponudbe na Madžarskem kot tudi njenih oblikah in intenzivnosti v različnih turističnih sezonah. Dodatno vrednost bi v tem smislu pomenila tudi raziskava, opravljena na strani povpraševanja, se pravi med slovenskimi turisti, ki obiskujejo Madžarsko, saj bi na takšen način lahko preverili dejanske motive za njihov obisk obravnavane države.

\section{Viri in literatura}

GZS (Gospodarska zbornica Slovenije), Turistične agencije z licenco. 2014. URL: http:// katalogi.gzs.si/zacetna_stran_kataloga.asp?kat=029 (citirano 13. 9. 2015).

HCSO (Hungarian Central Statistical Office). 2016a. Tourist arrivals and tourism nights in public accommodation establishments. URL: http://statinfo.ksh.hu/Statinfo/haDetails.jsp?query=kshquery\&lang=en (citirano 1. 3. 2016).

HCSO (Hungarian Central Statistical Office). 2016b. Foreign tourist arrivals and foreign tourism nights in public accommodation Establishments. URL: http://www.ksh.hu/ docs/eng/xstadat/xstadat_annual/iwnt001b.html (citirano 5. 3. 2016).

HCSO (Hungarian Central Statistical Office). 2016c. Time series of annual data - tourism (1960-). URL: http://www.ksh.hu/docs/eng/xstadat/xstadat_long/h_oga001.html (citirano 1. 3. 2016).

Itthon.hu - Turizmus Bulletin. 2016. URL: http://itthon.hu/site/upload/mtrt/Turizmus_Bulletin/bulletin_2006_balaton/html/balaton_jborturizmus.html (citirano 5. 3. 2016).

Kerma, S., Koderman, M., Salmič, S., 2009. Turisti iz Slovenije u hrvatskom primorju: obilježja i prostorni raspored turističkog prometa i internetske turističke ponude = Slovene tourists in the croatian littoral : characteristics and spatial pattern of tourist traffic and internet tourism offer. Geoadria, 14, 2, str. 249-272.

Kežar, M., Koderman, M., 2014. Avstrija v luči obiska turistov iz Slovenije: prostorska razporeditev turističnega prometa in spletne ponudbe slovenskih turističnih agencij. Geografski obzornik, 61,1/2, str. 32-39.

Kocsis, K., Schweitzer, F., 2009. Hungary in maps. Budapest, Geographical Research Institute, Hungarian Academy of Sciences, 211 str.

Koderman, M., 2015. "Nazaj v domači kraj": prostorske in turistične razsežnosti obiskovanja Slovenije s strani slovenskih izseljencev in njihovih potomcev iz Avstralije. Koper, Univerza na Primorskem, Znanstveno-raziskovalno središče, 219 str.

Koderman, M., Gosar, A., 2017. Cross cultural aspects of international guidebooks : Asian tourists in South Central Europe. V: Pearce, P. L., Wu, M. Y. (ur.). The world meets Asian tourists. Bingley, Emerald, str. 199-212. 
Koderman, M., Kerma, S., 2010. Značilnosti organiziranih potovanj turistov iz Slovenije v Bosno in Hercegovino. Annales, Series historia et sociologia, 20, 1, str. 201-216.

Litrop, J., 2003. Slovenski nakupovalni turizem na Madžarskem. Zbornik soboškega muzeja, 7, str. 137-155.

Papp, Z., A., 2011. Some social and demographic features of the hungarian diaspora in the West and its institutions. V: Bárdi, N., Fedinec, C., Szarka, L. (ur.). Minority Hungarian communities in the twentieth century. New York, Columbia University Press, str. 642-660.

Pečoler, N., 2013. Podoba Madžarske kot turistične destinacije v Sloveniji: vidik turističnih podjetij in turistov. Magistrsko delo. Ljubljana, Ekonomska fakulteta, 62 str.

SURS (Statistični urad RS). 2016a. Turistična potovanja v tujino po najbolj obiskanih evropskih državah in celinah, Slovenija, letno. URL: http://pxweb.stat.si/pxweb/Dia$\log$ /varval.asp?ma=2170208S\&ti=\&path=../Database/Ekonomsko/21_gostinstvo_turizem/06_potovanja/30_21702_znacilnosti_letno/\&lang=2 (citirano 1.3. 2016).

SURS (Statistični urad RS). 2016b. Prihodi in prenočitve turistov po vrstah občin, po vrstah nastanitvenih objektov in po državah, Slovenija, letno. URL: http://pxweb.stat. si/pxweb/Dialog/varval.asp?ma=2164505S\&ti=\&path=../Database/Ekonomsko/21_ gostinstvo_turizem/02_21645_nastanitev_letno/\&lang=2 (citirano 1. 3. 2016).

Tourism in Hungary, 1990-2002. Tourism regions of Hungary. URL: http://szakmai. itthon.hu/tourism-in-hungary-1990-2002 (citirano 1. 3. 2016).

Tourism in Hungary, 2015 - with preliminary data. 2016. Hungarian Tourism Ltd. URL: https:// www.google.si/url?sa $=$ t\&rct $=\mathrm{j} \& \mathrm{q}=\&$ esrc $=$ s\&source $=$ web\&cd $=2 \&$ sqi $=2 \& v e d=0 a h U-$ KEwjAote_1_zNAhVpCsAKHX61ACwQFggiMAE\&url=http\%3A\%2F\%2Fitthon. hu\%2Fdocuments\%2F880248\%2F24451017\%2FMTE_4001_105x210_LA4_StatElo_2015_ENG_TELJES_web.pdf\%2F8ea4af1f=-ee8d4101--a05a-bdbb800c9a1f\&usgAFQjCNFt9y2ztjBQ-rSgWyxBQHJXZMPpDg\&sig2=5d_1nxniRYSkUByDlX8mQ\&bvm=bv.127178174,d.ZGg\&cad=rja (citirano 4. 12. 2015).

UNESCO - Hungary. 2017. URL: http://whc.unesco.org/en/statesparties/hu (citirano 18. 7. 2017).

UNWTO (World Tourism Organization). 2015. Tourism highlights 2015. URL: http:// www.e-unwto.org/doi/pdf/10.18111/9789284416899 (citirano 5. 3. 2016).

WTTC (World Travel \& Tourism Council). 2016a. Economic impact 2016 - Hungary. URL: http://www.wttc.org/-/media/files/reports/economic\%20 impact \%20research/ countries\%202016/hungary2016.pdf (citirano 5. 3. 2016).

WTTC (World Travel \& Tourism Council). 2016b. Economic impact 2016 - Slovenia. URL: http:/www.wttc.org//media/files/reports/economic\%20impact\%20research/countries\%202016/slovenia2016.pdf (citirano 5. 3. 2016). 


\section{SLOVENIAN TOURISTS IN HUNGARY - SPATIAL DISTRIBUTION OF TOURIST FLOWS AND ANALYSIS OF THE INTERNET-BASED TOURISM SERVICES}

\section{Summary}

Hungary established itself as a major tourist destination decades ago, when it became renowned for its thermal spas and rich cultural and architectural heritage of the former Austro-Hungarian monarchy. In the recent years, the country has attracted tourists and daily visitors with a diverse tourism offer, which ranges from activities in natural protected areas with high levels of biodiversity to international festival events and famous traditional culinary and wine products. In 2015, the country recorded over 10 million tourist arrivals, among which domestic tourists prevailed. Due to geographical vicinity, as well as historical, social and political similarities, Hungary also represents a popular destination for visitors and tourists from Slovenia.

According to the Statistical office of the Republic of Slovenia, about 46,000 tourists from Slovenia visited Hungary in 2014. This number is based on the criterion of at least one overnight stay in Hungarian accommodation establishments and is therefore underestimated in regard to the number of Slovenian visitors, since many Slovenians visit this country in a single day. In the paper, authors analyze the spatial distribution of tourist traffic and present the main characteristics of (organized) Slovenian tourist visits to Hungary. The main part of the research is focused on the analysis of the internet-based tourist offer, provided by Slovenian travel agencies. The offer was subjected to a detailed review that concentrated on its spatial distribution, types of advertised tourist activities, financial value and duration of travel. 